\title{
Health Care and Migration: What Data Can Tell Us of the Hard-to-Measure Impact of Migrants on the European Health Systems
}

\author{
Guidi Caterina Francesca and Alessandro Petretto
}

\section{Background Framework}

One of the most fascinating aspects of health as a good is the different perspectives from which it can be studied since it has direct effect in the quality of life of individuals: guaranteeing its coverage and provision is a question of both equity and humanity. According to the consolidate literature of the Public Choice Theory (Samuelson 1954), health is a merit good (Musgrave 1959) with certain characteristics (Arrow 1963) present in both the demand and supply sides-such as externalities, information asymmetry, good experience, doctor-patient relationship, moral hazard, the adverse selection phenomenon (linked to uncertainty), and paternalistic public supply (Petretto 2017). Given these economic characteristics, health should be provided according to individuals' needs, a concept more related to the sphere of equity, rather than their ability or willingness to pay linked to the efficiency dimension. By its own nature, healthcare is an input into a productive process: medical treatment has a consumption effect-individuals feel better when they are healthier-and is an investment - the healthier you are, the more active in the labour market you are (Grossman 1972).

On the supply side, the two magisterial aspects are the provision model and pricesquantity of healthcare treatments available in the market, while on the demand side the three very important characteristics that we aim to investigate are access,

The original version of this chapter was revised. A correction to this chapter is available at https://doi.org/10.1007/978-3-030-11361-2_14.

G. Caterina Francesca $(\bowtie)$

European University Institute, Fisole, Florence, Italy

e-mail: caterina.guidi@eui.eu
A. Petretto $(\bowtie)$
University of Florence, Florence, Italy
e-mail: alessandro.petretto@unifi.it 
utilization, and quality of the outcome. In this chapter, we want to deepen the first two aspects - access and use — and study them according to the European welfare system provision towards migrants, one of the most vulnerable groups in European societies. We concentrate our study on what data and empirical evidence can tell us of the hardto-measure impact of migrants on European health systems.

One of the most compelling challenges is the adaptation of the health systems to migration's and mobility's new needs. Worldwide around 70\% of people still lack social protection coverage (ILO 2014) and about 400 million people do not have access to health services (WHO and WB 2015); among them the most vulnerable are migrants (OECD 2017). The adaptation of health systems to the migration phenomenon implies costs that can generate sustainability problems in the provision of services for nationals.

International migration represents $3.4 \%$ of the global population; considered as a whole, it would constitute the fifth-largest population in the world after China, India, the European Union (EU), and the United States of America (USA) (UNDESA 2017). Nearly two-thirds of all international migrants, around 76 million people, live in Europe (UNDESA 2017), establishing the continent as a recent migration destination. Indeed, between the Age of Discoveries and the mid-twentieth century, some 70 million people left their European homeland for overseas destinations and only in the last three decades has the number of third-country nationals entering the EU been greater than the number of EU citizens leaving for overseas destinations (Münz 2017). Today, almost 57.3 million citizens born outside their country of origin, accounting for $11 \%$ of the total population, equal to approximately 512 million people on 1 January 2017, in turn composed of 36\% intra-EU migrants and 64\% of foreign-born (Eurostat 2017). Around $6 \%$ of the latter group is represented by a growing second generation of migrants who have one or two foreign parents (Münz 2017).

To this we should add the so-called "humanitarian crisis", which has been worsened after the geopolitical imbalance post-9/11 and the Arab Spring uprising (Dustmann et al. 2016). In the years 2014-2016, about 1.8 million people (IOM 2017) entered EU ports in an irregular manner, mainly through the Mediterranean and the Western Balkans. More than 35\% arrived for humanitarian reasons, asking for asylum in various Northern and Western EU countries, creating a pressure never felt before on the European reception system (UNHCR 2017). This extra inflow-in addition to some 2 million first-residency permits issued to third-country nationals yearly - was unprecedented in size. In fact, in the years 2000-2013, the EU countries had only admitted fewer than 4 million asylum seekers and refugees altogether; on average fewer than 300,000 per year (Münz 2017).

The EU MS present different situations in terms of healthcare models, taxation systems, and the integration of foreign nationals. Compared to other countries with longer migration histories, such as Canada and the USA, the differences in access and use of health systems for foreigners are further differentiated according to their legal status - such as asylum seekers, refugees, long-term residents and so on.

In this chapter, we will analyze the health care provision for the European migrant population, underlining the differences between healthcare systems. Migration, indeed, may create more pressure on consolidated services or require new ones and can affect the demand and supply of health goods and care. In the next paragraph, we 
will consider the terms in which economic analysis addresses the complexity of migrant health needs. In the third paragraph, we will present the main themes for adapting the concept of health inequalities to the phenomenon of migration in Europe. The fourth paragraph is devoted to a concise review of the main types of healthcare and welfare systems in Europe. Concluding, the fifth paragraph contains some final considerations. The extensive bibliography we propose provides an idea of how much attention in this historical phase economic and econometric analyses have devoted to the implications of the migration phenomenon.

It is not possible to draw unequivocal and definitive conclusions from this review: The impact of migration on the welfare of industrialized countries is broad and heterogeneous, especially with regards to consolidated public economics and requires more in-depth and innovative theoretical reflections. Migration is a complex human phenomenon that imposes an arduous challenge to all social sciences, and public economics will certainly not come out of this without an inevitable methodological revision.

\section{Complexity of Migrant Health Needs and an Economic Analysis}

The classic Economics of Migration is focused on neoclassical models (Bencivenga and Smith 1997; Harris and Todaro 1970; Todaro 1969) and based on maximizing utility function and the New Labour Economics theories (Stark 1991, 1978). In the mainstream literature, the push and pull factors of migratory processes - such as expected salary, income, investment in human and social capital-have been analyzed in several contributions (Massey et al. 1993; Sjaastad 1962), particularly in Europe (Fouarge and Ester 2007; Hatton and Williamson 2002). The risk diversification in the choice of countries of destination (Simon 1983; Katz and Stark 1986) as the reason for the different investment in capital-cultural, financial, symbolic, and social capital (Bourdieu 1986) — tried to give an exhaustive portrait of migration economics, describing particularly what happens on the demand side of migration. In addition, the recent contributions to behavioural economics (Bertoli et al. 2015; Czaika 2015; Mankiw 1998; Kahneman and Tversky 1979), enrich the theoretical reference framework addressing the migrant perspective. In fact, the individual as the ethnic group beliefs towards destination countries and the functioning of the social networks are studied and considered to define the migratory investment or the aversion for status quo loss.

However, attention to the impact of migrants on destination country welfare systems is still scarce, especially in Europe. Some scholars, most notably Borjas (1994, 1999), argue that the various model of European welfare serves as a magnet for migrants given its average generosity and the high vulnerability suffered by people in transit, who are escaping from poverty, wars, and natural disasters. Brücker et al. (2002) have shown that, although it persists after controlling for migration characteristics, the effects of welfare attraction on migration composition are very moderate, and much more relevant than those exercised by wage levels or the expected unemployment rate in the destination countries (De Giorgi and 
Pellizzari 2009). Boeri (2009) found that less-skilled migrants are over-represented in the countries with more generous welfare and a higher probability to receive non-contributory benefits than natives, such as in Denmark, Finland, Norway, and Sweden, while the opposite happens in countries such as Austria, Germany, Spain, and the United Kingdom. However, this effect was not proven during the current refugee crisis in Europe: referring to a previous study (Pedersen et al. 2008), only a small proportion of asylum seekers declared they had chosen France due to the generosity of its welfare system. The analyses that utilize the level of public social expenditures out of the Gross Domestic Product (GDP) - in particular, public health care expenditure as a proxy for social state attractivity-do not support the magnet hypothesis (Gubert and Senne 2016).

Borjas and Trejo (1991) studied the public reception and assistance system of migrants in the USA and suggested that during the 1970s their increased utilization of assistance services may have been assessed by a change in the composition of cohorts of immigrants in terms of nationalities and time spent in the country. As also affirmed by Borjas and Hilton (1996), immigrants were more likely to be part of the Medicaid program in the 1980s and 1990s than the latest demographic cohorts. Implicitly, therefore, an increase in migration flows would add pressure on health resources (Preston 2014).

Hansen and Lofstrom (2003) looked at the use of the welfare system by migrants in Sweden, concluding that they are more likely to make use of its services than natives, but the effect decreases with the length of stay, as confirmed by Sarvimäki (2011) in Finland. Bratsberg et al. (2010, 2014), on the contrary, found migrants in Norway performed worse in the labour and social security market.

Barrett and McCarthy (2008) summarized most of the existing literature focusing on the nature of welfare systems in the destination countries and the use intensity made by migrants. They found that in Ireland immigrants are less welfare-dependent than natives, while in the United Kingdom they are more likely to use it: this effect, however, depends entirely on the higher dependence of Irish citizens on their welfare system. On the other hand, Dustmann et al. (2010) showed that there is a net benefit for the UK produced by migrants from countries entering the European Union in 2004. In fact, migrants from the $\mathrm{A} 8^{1}$ countries are much younger and then more likely to join the workforce and, therefore, less likely to benefit from social benefits, taking into account the eligibility criteria that non-EU migrants face. Dustmann and Frattini (2014) extended their analysis to immigrants from all countries, demonstrating once again the low levels of receiving benefits and the use of social housing in comparison with natives.

Grönqvist et al. (2012), studying the residential placement of asylum seekers in Sweden, analyzed the causal effects of health ethnic segregation and found that a positive association is observed between ethnic concentration and poor health outcomes-including hospital admissions-but this disappears when controlling for residence status.

${ }^{1}$ Czech Republic, Estonia, Hungary, Latvia, Lithuania, Poland, Slovakia, Slovenia. 
However, the health of migrants is one of the biggest challenges for public health, causing serious problems of inequality and social exclusion in the destination countries. Understanding variables - founders and co-founders - is a fundamental exercise for studying the determinants of access, use, and quality of health services. Migrant health poses the central issue of public finance emerging from the social inclusion process: defending the sustainability of healthcare systems on the financial side is a prerequisite for tackling and winning this great challenge in Europe.

\section{Migrant Health Status in the Health Care Debate: From the Healthy Migrant Effect to the Exhausted Migrant Effect}

According to their specific framing, countries provide various levels of health coverage for different migratory groups and have different criteria for what is considered as a medical emergency (Stanciole and Huber 2009; Cuadra 2011; FRA 2011). The literature devoted to health, ethnic, and social inequalities is increasingly popular and explores several aspects of this topic, such as the higher risk of certain diseases among ethnic minorities (Hadjar and Backes 2013; Smith Nielsen and Krasnik 2010), the adopted behaviours, and the differences in the organization of health systems (Blom et al. 2016) as in the healthcare consumption for asylum seekers (Essink-Bot et al. 2012) and irregular migrants (Suess et al. 2014).

Historically, the hypothesis of the healthy migrant effect (HME) states that migrants have a better health status than non-migrants in the country of origin (Abraído-Lanza et al. 2000) thanks to a sort of comparative advantage (AcevedoGarcia et al. 2010), confirming that immigrants are not a sample of the population of origin but a positive health-based selection (Giuntella et al. 2016). Migrants from low-income countries have been described as "travellers of time" from the past and therefore have been exposed to fewer health risks, particularly for non-communicable diseases (Razum and Twardella 2002). However, it has recently been shown that being a migrant can be a decisive factor that negatively determines their health (Rechel et al. 2011), from arrival to stay in the destination countries (Marmot 2005; Marmot et al. 2012; Davies et al. 2009; Malmusi 2014; Giuntella and Stella 2017). Concurrent mechanisms such as poverty, discrimination in the labor market, travel, and living conditions in the host countries can influence migrants' opportunities in terms of healthcare received and suffered diseases, affecting the deterioration of their health over time (Acevedo-Garcia et al. 2010; Rechel et al. 2013). This is also known as the exhausted migrant effect, which also affects the health of second-generation migrants (Devillanova and Frattini 2016): a natural regression process towards the average health of the population (Giuntella 2013), an unhealthy assimilation process (Antecol and Bedard 2006; Giuntella and Stella 2017), and more likely to do dangerous work (Orrenius and Zavodny 2013; Giuntella and Mazzonna 2015). Additionally, adversities may be the cause of an 
increased incidence of mental disorders such as schizophrenia (Ingleby et al. 2012), anxiety, and depression (Lindert et al. 2009) among migrants. In some European countries, social exclusion and marginalization, which have also occurred since the second generation, seem to have a devastating effect.

Recently, Moullan and Jusot (2014) found that the differences in the health status of migrants and natives in Europe could be attributed to the large variation in health status of citizens in different European MS and countries. It has also shown that in times of economic crisis-given the high levels of unemployment and retirement uncertainty - migrants prefer to return to their country of origin for the salmon bias effect (Razum 2006). Indeed, the unhealthy re-migration effect is proven: migrants who have decent lives register a lower mortality risk in the host country than those whose migration has been ruinous, returning home even before they become manifestly sick (Razum et al. 2001).

The theory of acculturation - rather than the adoption of norms, values, and behaviours of the host countries - has been used to explain the changes in migrant health behaviours in the United Kingdom (Jayaweera and Quigley 2010) and in the USA (Giuntella 2016). Migrants present higher smoking levels than nationals, lower breastfeeding levels, and more high-fat diets, with a consequent increase in diabetes, cardiovascular disease, and cancer or, as in the case of Germany (Sander 2007), adverse mental health (Brand et al. 2017). If this theory is true, second or third generations of migrants may have similar health habits, like the local population of origin, as proved recently in the USA (Giuntella and Stella 2017) with the acceleration of obesity rates in the most recent migrant cohorts.

While the definition of who is an immigrant is recognized at the international level, it is still not very clear after how many years migrants can be considered part of the local population and their health risks like those of the local population (Grosser et al. 2016). In some countries, the second generation acquires the reception country's citizenship at birth—jus soli — while in others migrants remain "foreign" or "aliens" until the legal age (18 or 16 years old) or after some years of permanent residence-jus sanguinis (WHO 2010).

As stated by Razum (2006), an ideal migrant study should follow individuals before they migrate to the country of destination and, in the event of a return migration, back to the country of origin to better understand the direction of these effects and provide a real measurement.

\section{The Organization of the European Welfare Systems: Some Evidence}

\subsection{The Different European Welfare Systems Typologies}

The depth of health coverage, together with spending patterns and funding targets, are fundamental factors in determining the cost of the protection protection of the health for a country's citizens (Balabanova et al. 2013) as for the most vulnerable 
groups. Although health variability is linked to individual factors, the country of residence determines the quantity and supply of health services: In some European countries, populations are healthier due to the health coverage or levels of commodity of healthcare services (Bambra 2006; Mackenbach 2012; Eikemo et al. 2008a, b). Therefore, the famous distinction between countries based on welfare systems (Esping-Andersen 1990; Ferrera 1996; Petretto 2017) is central and differentiates countries into five groups: Anglo-Saxons, Bismarckian, Eastern, Scandinavian, and Southern, according to the liberal, conservative, post-socialist, or social-democratic policies pursed in the public sector. In Europe, countries are divided as follows:

- Anglo-Saxon: Ireland (IE) and England (UK);

- Bismarckian: Austria (AT), Belgium (BE), France (FR), Germany (DE), Luxemburg (LU), Netherlands (NL), and Switzerland (CH);

- Eastern: Bulgaria (BG), Czech Republic (CZ), Croatia (HR), Estonia (EE), Hungary (HU), Latvia (LV), Lithuania (LT), Poland (PL), Romania (RO), Slovak Republic (SK), and Slovenia (SL);

- Scandinavian: Denmark (DK), Finland (FI), Norway (NO), and Sweden (SE);

- Southern: Cyprus (CY), Greece (EL), Italy (IT), Malta (MT), Portugal (PT), and Spain (ES).

The social-democratic systems try to ensure wealth redistribution through laws and social security institutions, while the conservative systems present a low threshold of finance redistribution and a lower level of social welfare, but they respect the principle of subsidiarity. In contrast, liberal welfare regimes support a free-market economy with occasional interventions by the state and an average level of wellbeing guaranteed by the market while the post-socialist regimes have different mechanisms to produce welfare in their transition economies.

The idea is that the welfare system is central for migrant integration in terms of coverage and resources (Hadjar and Backes 2013). In addition, European healthcare systems differ from one country to another in various aspects such as the type of financial contribution, which influences the medical care provided to citizens and migrants. In summary (Thomson et al. 2009):

- National Health Service (NHS): the health services are mainly financed through taxation as in DK, ES, FI, IE, IT, MT, NO, PT, SE, and the UK;

- Social Health Insurance (SHI): social contributions are the main financial instrument; it is the most popular system in Europe as in AT, BE, CH, CZ, DE, EE, FR, HR, HU, LT, LU, NL, PO, RO, SK, and SL;

- Out-of-pocket payment (OOP): it is based only on private payment and very few European countries present this system as in BG, CY, EL, LV.

Although there is a positive trend in increasing funds for health spending and social protection (Honorati et al. 2015), comparing EU MS with other non-EU countries, some selected health expenditure flows present very high variability, as illustrated in Fig. 1.

Current health expenditure, as a proportion of GDP, has increased over the past decades in most EU countries: for the EU as a whole, it has increased from $7.9 \%$ in 


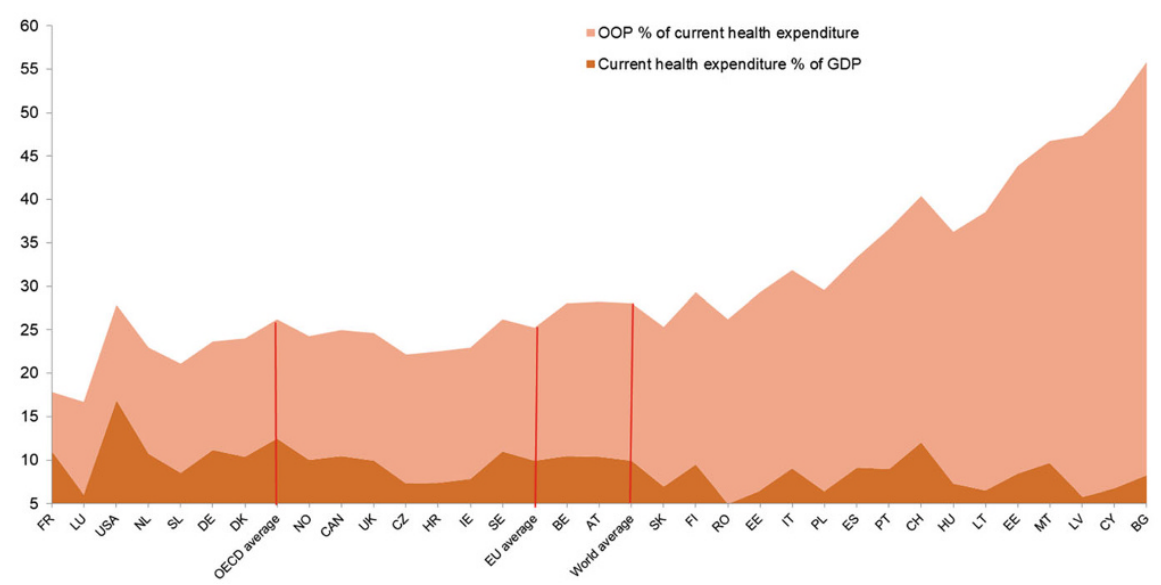

Fig. 1 Trends in current and private healthcare expenditure in EU MS, Canada, Norway, Switzerland, USA-2015. Source: Authors' elaboration based on data provided by World Bank-World Development Indicators (2018)

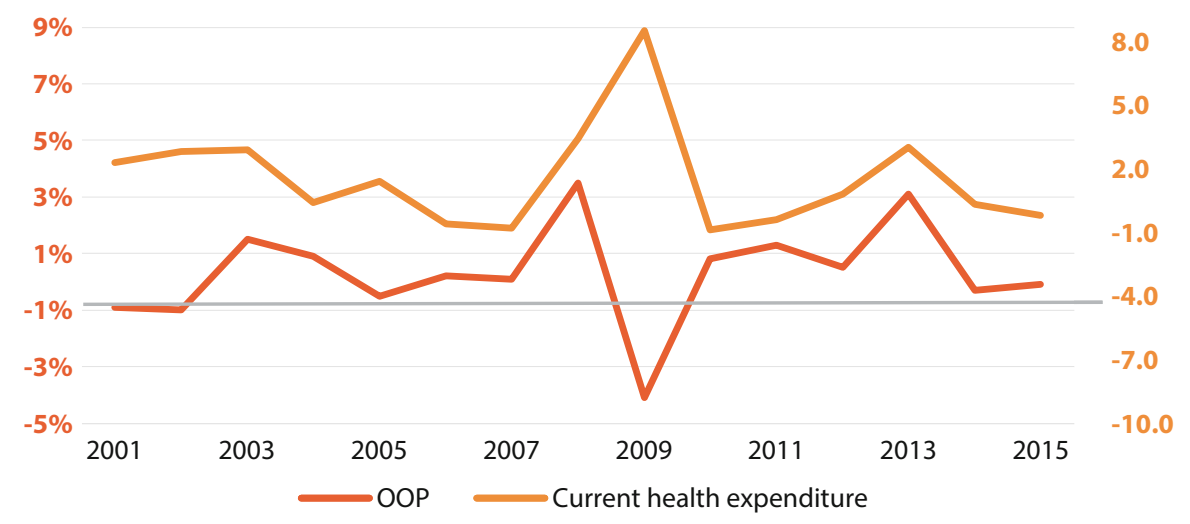

Fig. 2 Growth rates in currentand private health expenditure from 2001 to 2015 in the EU. Source: Authors' elaboration based on data provided by World Bank-World Development Indicators (2018)

2000 to $9.9 \%$ in 2015 , while the share of OOP out of THE has substantially decreased in some countries and increased in others. As shown in Fig. 2, from the comparison between total and OOP health expenditure growth rates from 2001 to 2015 , it can be noted that a decrease in the first corresponds an increase in the other and the current European trend is a progressive increase of OOP proportion of the private health expenditure (OECD and WB data 2017).

As shown in Fig. 3, assuming 2010 as the worst year in the panel of time crisis, in countries where the proportion of OOP expenditure out of the private health expenditure (PHE) increases, the Gini Index, which measures inequality in income distribution, follows the same path, determining a higher effect of health inequalities. 


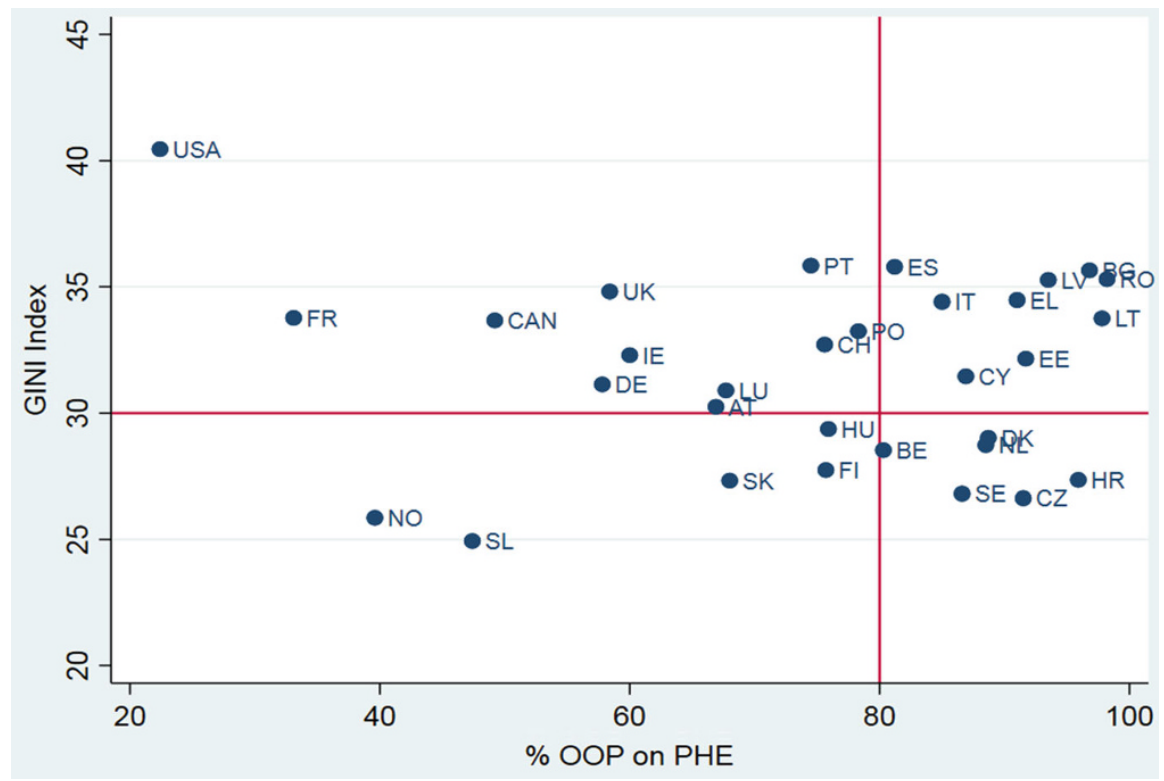

Fig. 3 Health inequality EU MSs, Canada, Norway, Switzerland, USA-2010. Source: Authors' elaboration based on data provided by World Bank-World Development Indicators (2018)

However, it is not easy to determine its final effect on health (European Commission 2013). The proportion of individuals covered by a private insurance varies widely among MS (Thomson et al. 2009): close to zero in CZ, ES, IC, LT, RO, and SV while FR, BE, LU, Sl, and NL present half of the population with access to private insurance, given that it can be complementary, supplementary, or duplicative to their health systems. Indeed, in more than one-third of EU countries, healthcare systems are financed by a mix of taxation and social contributions.

This does not lead to a unique impact on migrants in an EU characterized by deep structural differences and oppressed by a global economic and financial crisis (Dustmann et al. 2016). In addition, the socioeconomic inequalities of mortality and morbidity are no smaller in Scandinavian and SSN welfare countries than in the liberal Anglo-Saxon countries or those characterized by a Southern system or with more family-oriented public policies (Eikemo et al. 2008a, b).

Certainly, the educational gradient plays a central role since countries with the lowest average years of education — such as the Southern and Eastern European countries_-present the largest overall prevalence rates of illness, while the AngloSaxon countries have the lowest ones (Eikemo et al. 2008b). In general, first Scandinavian and then Anglo-Saxon regimes were observed to have better selfassessment (SAH) than Bismarckian, Southern, and Eastern European welfare regimes given that the variety of cultural factors may influence the rational expectations of citizens (Navarro et al. 2003, 2006; Bambra 2006; Borrell et al. 2007; Eikemo et al. 2008a; Bambra and Eikemo 2009; Bergqvist et al. 2013). 


\subsection{Healthcare Expenditure and Reduction of Ethnic Inequalities}

The study of the impact of healthcare expenditure on reducing ethnic inequalities has recently received more attention since it might amplify differences between migrants and natives, especially first-generation immigrants (Blom et al. 2016). Taking for granted the hypothesis of the material deprivation and intersectionality of different disadvantages affecting migrants, it has been proved that language and cultural barriers impede the access and use of services despite the percentage of health expenditure dedicated (Ingleby 2012). Therefore, policies on socioeconomic deprivation may reach the lower quintiles of income but mostly native residents rather than migrants (Palencia 2014); while specific policy measures targeted to migrant health may really reduce these disadvantages (Mladovsky 2011), they may lead to friction between the poor with unforeseeable outcomes.

A further element of difference between the countries is the migrant integration policy model, based on the Migrant Integration Policy Index (MIPEX) scores produced by the Migrant Policy Group (Meuleman and Reeskens 2008). The main categories of countries are as follows:

- Assimilationist: based on the premise that migrants can be socially and culturally absorbed into the societies through a process of adaptation as in $\mathrm{CH}, \mathrm{FR}, \mathrm{DE}, \mathrm{IE}$, and LU;

- Exclusionist: where migrants are incorporated in certain spheres of life and excluded from others as in AT, BG, CY, CZ, DK, EE, EL, HU, LV, LT, MT, PO, RO, SL, and SK;

- Multiculturalist: where ethno-cultural groups are given equal rights as the majority population in the different spheres of social life as in BE, ES, FI, IT, NL, PT, SE, and UK.

The number of studies utilizing MIPEX in their analyses to characterize the healthcare provision to different classes of citizens in European countries is considerable. A relationship between MIPEX and depression levels in migrants has been proven (Levecque and Van Rossem 2015), while it has not been found so explicative for comparing the subjective wellbeing of migrants and natives (Hadjar and Backes 2013) Malmusi (2014). Giannoni et al. (2016) demonstrated the impact of the migration policy on migrants' SAH: indeed, unsufficient integration policies worsen socioeconomic and health outcomes. As expected, countries that rely on the OOP system and adopt exclusionist policies also present lower percentages of public health expenditure while the majority of those with the NHS system also present a multicultural policy, asking their citizens lower percentages of out-of-pocket tax contributions.

As expected, countries relying on an OOP healthcare system and exclusionist policies also have lower public health spending, while most countries with SSNs also have a multicultural integration policy, requiring percentages of private personal contribution to lower health care. As empirical evidence shows, minority ethnic groups may have more health problems-higher mortality risk and lower levels of 
wellbeing - in European countries with more severe integration policies (Ikram et al. 2015; Hadjar and Backes 2013). The perceived group discrimination is associated with poor health outcomes in the first generation of migrants in Europe (Levecque and Van Rossem 2015) but not among their descendants, in particular in the assimilationist countries (Borrell et al. 2015). The length of stay, the acquisition of citizenship, and naturalization mitigate health exclusions and then the poor health outcomes after the first generation.

Several authors have demonstrated that health inequalities between migrants and non-migrants decrease or disappear, controlling their socioeconomic position (SEP). However, some authors argue that SEP can in turn be conditioned by ethnic origin and migrant status, and so caused by social exclusion processes (Davies et al. 2009; Malmusi et al. 2010; Rechel et al. 2013). As such, it should be treated as an unlawful inequality component (Mackenbach 2012) that must be overcome, as ethnic differences in the health sector should only be justified if the healthcare received meets the different health needs of all groups (Essink-Bot et al. 2012).

In addition, as shown in Fig. 4, the relationship between MIPEX health and the assessment of the quality of its health system extracted from the Eurobarometer (2014) confirms our intuition. On the vertical axis, the health policies in support of migrants in the EU MS are reported while the percentages of people who replied "Good" to the question "How do you evaluate the overall quality of your healthcare system?" are on the horizontal axis.

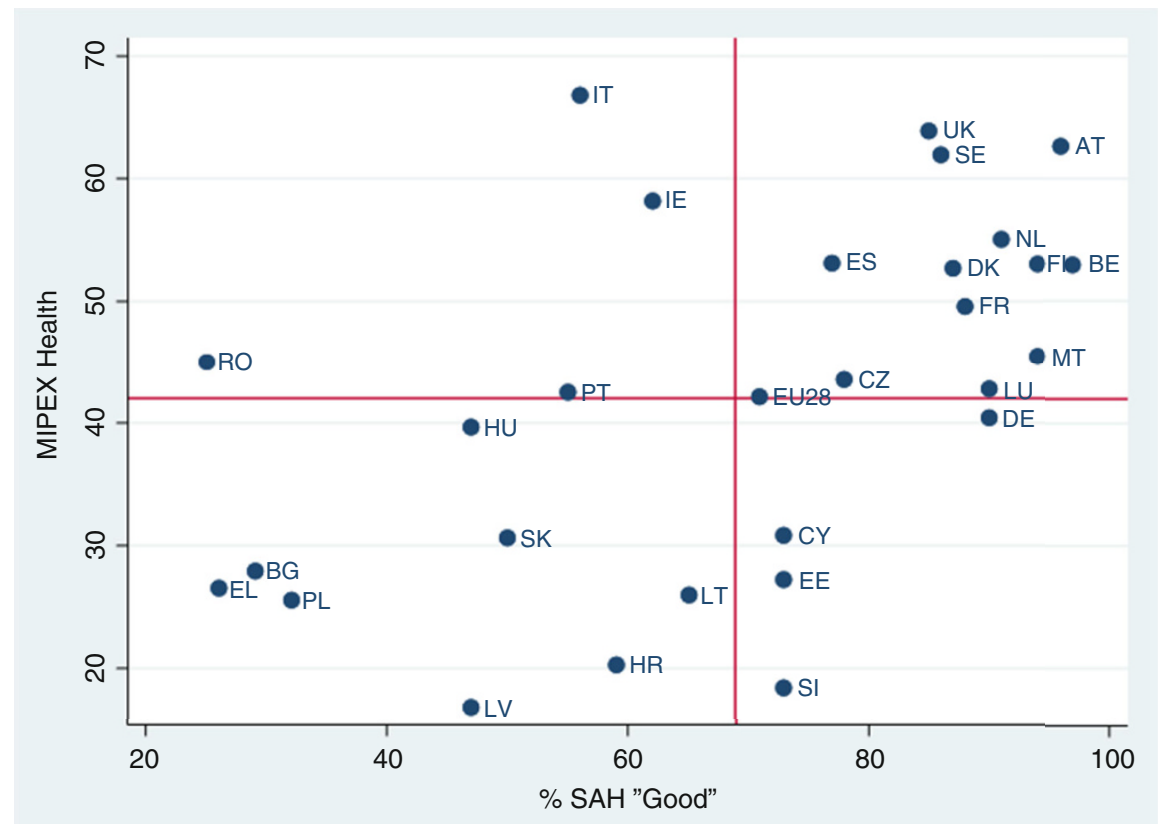

Fig. 4 MIPEX Health and Eurobarometer in EU MSs-2015. Source: Authors' elaboration on Eurobarometer (2014) and MIPEX Health (2015) data 
As can be seen, some country clusters are emerging: Eastern countries adopting exclusionist policies and with SHI or OOP financing systems provide the worse results in terms of migrant health, while Anglo-Saxon and Bismarckian countries, irrespective of the migration policies but presenting an NHS or SHI financing system, register the best performances. Indeed, migrant health seems to be strictly correlated with the overall healthcare system function and citizen satisfaction.

\section{Conclusions}

In this chapter we have analyzed the provision models of health care to migrant population, according to European healthcare systems. Migration, by creating more pressure on consolidated services or requiring new ones, affects the demand and supply of health goods. We first tried to consider the terms on which economic analysis addresses the complexity of migrant health needs, and then considered the adapting of health inequalities to the phenomenon of immigration. Second, we reviewed the main types of healthcare and welfare. There aren't any "one size fits all" conclusions applicable to all countries, proving that immigration is totally beneficial for public finances. There is also empirical evidence that encourages the affirmation that it is not a process that can be avoided in the history of humanity itself, especially in turbulent times: measuring the impact of migration on healthcare systems is an emerging issue for developed as well as developing countries, and contributes to the evaluation of the overall wealth of countries in providing services to their citizens.

We believe that, in the present state of art in public economics, it is not possible to draw unequivocal and definitive conclusions regarding the problem faced in this review: the theme is so broad, complex, and heterogeneous that it requires more in-depth and innovative theoretical reflections. Almost all the fundamental theorems are based on a given population and in absence of mobility, but migration is not just mobility. Migration is a complex human phenomenon that imposes an arduous challenge to all social sciences, and public economics will certainly not come out of this with an inevitable methodological revision.

On the specific issue of the impact on European public finances, there is no evidence that in Europe, legal migrants, especially the highly qualified ones, are net beneficiaries of social transfers by the state even though there is a residual dependence on their non-contributory character and that migrants are more likely to approach countries with more generous welfare systems (Preston 2014; Boeri 2009; Boeri et al. 2002). In several countries migrants have thus largely supported the local public finances and not affected public health sector performances (Alfano et al. 2016; Devillanova and Frattini 2016; Gimeno-Feliu et al. 2016; Giuntella and Mazzonna 2015; Wadsworth et al. 2016; Wadsworth 2013; Dustmann and Frattini 2014; Gee and Giuntella 2011; Steventon and Bardsley 2011).

Closing the doors of the welfare state (Boeri and Brücker 2005) should never be a solution for European countries, particularly in the health sector where it could 
generate pandemic emergencies of preventable diseases and create marginalized and excluded individuals, by definition, from health coverage. As explained by Alesina et al. (2001), Europeans have a greater public welfare state to offer than Americans since they are more likely to pursue redistribution policies, even when in favour of ethnic and racial minorities.

Moreover, according to Preston (2014), the economic and fiscal equilibrium between the different effects depends, inter alia, on the nature of fiscal and expenditure rules, the pressures of selection processes on the composition of migrants, and the stages of the economic cycle.

The problem will soon not be checking the economic and financial constraints and impacts on the welfare systems of the migratory phenomenon but rather equip the welfare systems themselves for a heterogeneous population in terms of average income and wealth levels. In this regard it is worth remembering Rechel et al. (2013) and Davies et al. (2009) who, using European datasets, found that health discrepancies between migrants and non-migrants disappear after control over their socioeconomic positions. In other words, the sustainability of health systems, within the broader welfare systems, will increasingly target the measures to contrast social inequalities rather than help the migratory phenomena as such: and it will concern the whole population, migrants as well as natives.

\section{References}

Abraído-Lanza, A. F., Dohrenwend, B. P., Ng-Mak, D. S., \& Turner, J. B. (2000). The Latino mortality paradox: a test of the "salmon bias" and healthy migrant hypotheses. American Journal of Public Health, 89(10), 1543-1548.

Acevedo-Garcia, D., Bates, L. M., Osypuk, T. L., \& McArdle, N. (2010). The effect of immigrant generation and duration on self-rated health among US adults 2003-2007. Social Science \& Medicine, 71(6), 1161-1172.

Alesina, A., Gaesler, E., \& Sacerdot, B. (2001). Why doesn't the US have a European-style welfare state? (Harvard Institute of Economic Research Working Papers 1933). Cambridge, MA: Harvard University Press.

Alfano, M., Dustmann, C., \& Fasani, F. (2016). Immigration and the UK, Reflections after Brexit (CREAM, Discussion Paper Series CPD 23/16). London.

Antecol, H., \& Bedard, K. (2006). Unhealthy assimilation: Why do immigrants converge to American health status levels? Demography, 43(2), 337-360.

Arrow, K. (1963). Uncertainty and the welfare economics of medical care. American Economic Review, 53(5), 941-973.

Balabanova, D., Mills, A., Conteh, L., Akkazieva, B., Banteyerga, H., Dash, U., Gilson, L., Harmer, A., Ibraimova, A., Islam, Z., Kidanu, A., Koehlmoos, T. P., Limwattananon, S., Muraleedharan, V. R., Murzalieva, G., Palafox, B., Panichkriangkrai, W., Patcharanarumol, W., Penn-Kekana, L., Powell-Jackson, T., Tangcharoensathien, V., \& McKee, M. (2013). Good health at low cost 25 years on: Lessons for the future of health systems strengthening. Lancet, 381(9883), $2118-2133$.

Bambra, C. (2006). Health status and the worlds of welfare. Social Policy and Society, 5, 53-62.

Bambra, C., \& Eikemo, T. A. (2009). Welfare state regimes, unemployment and health: A comparative study of the relationship between unemployment and self-reported health in 23 European countries. Journal of Epidemiological Community Health, 63, 92-98. 
Barrett, A., \& McCarthy, Y. (2008). Immigrants and welfare programmes: Exploring the interaction between immigrants' characteristics, immigrant welfare dependence and welfare policy. Oxford Review of Economic Policy, 24(3), 542-559.

Bencivenga, V., \& Smith, B. D. (1997). Unemployment, migration and growth. Journal of Political Economy, 105(3), 582-608.

Bergqvist, K., Åberg Yngwe, M., \& Lundberg, O. (2013). Understanding the role of welfare state characteristics for health and inequalities: An analytical review. BMC Public Health, 13., 1234, $1-20$.

Bertoli, S., Docquier, F., \& Ruyssen, I. (2015). Networks and migrants' intended destination, Paper presented at the GDRI Workshop on International Migration, CERDI, Clermont-Ferrand, November 2015.

Blom, N., Huijts, T., \& Kraaykamp, G. (2016). Ethnic health inequalities in Europe. The moderating and amplifying role of healthcare system characteristics. Social Science \& Medicine, 158, 43-51.

Boeri, T. (2009). Immigration to the land of redistribution. Economica, 77, 651-687.

Boeri, T., \& Brücker, H. (2005). Why are Europeans so tough on migrants? Economic Policy, (44), 629-704.

Boeri, T., Hanson, G., \& McCormick, B. (Eds.). (2002). Immigration Policy and the Welfare System. Oxford: Oxford University Press.

Borjas, G. (1994). The economics of immigration. Journal of Economic Literature, 32(4), 1667-1717.

Borjas, G. (1999). Immigration and welfare magnets. Journal of Labor Economics, 17(4), 607-637.

Borjas, G., \& Hilton, L. (1996). Immigration and the welfare state: Immigrant participation in means-tested entitlement programs. Quarterly Journal of Economics, 111(2), 575-604.

Borjas, G., \& Trejo, S. (1991). Immigrant participation in the welfare system. Industrial and Labor Relations Review, 44(2), 195-211.

Borrell, C., Espelt, A., Rodriguez-Sanz, M., Navarro, V., \& Kunst, A. E. (2007). Explaining variations between political traditions in the magnitude of socio-economic inequalities in selfperceived health. In Tackling Health Inequalities in Europe: Eurothine. Rotterdam: Erasmus Medical Center.

Borrell, C., Palència, L., Bartoll, X., Ikram, U., \& Malmusi, D. (2015). Perceived discrimination and health among immigrants in Europe according to national integration policies. International Journal of Environmental Research and Public Health, 12, 10687-10699.

Bourdieu, P. (1986). The forms of capital. In J. Richardson (Ed.), Handbook of theory and research for the sociology of education (pp. 241-258). New York: Greenwood.

Brand, T., Samkange-Zeeb, F., et al. (2017). Acculturation and health-related quality of life: Results from the German National Cohort migrant feasibility study. International Journal of Public Health, 62(5), 521-529.

Bratsberg, B., Raaum, O., \& Røed, K. (2010). When minority labor migrants meet the welfare state. Journal of Labor Economics, 28(3), 633-676.

Bratsberg, B., Raaum, O., \& Røed, K. (2014). Immigrants, labour market performance and social insurance. Economic Journal, 124(580), 644-683.

Brücker, H., Epstein, G., McCormick, B., Saint-Paul, G., Venturini, A., \& Zimmermann, K. (2002). Managing migration in the European welfare state. In T. Boeri, G. Hanson, \& B. McCormick (Eds.), Immigration policy and the welfare system: A report for the fondazione rodolfo debenedetti (pp. 1-167). Oxford: Oxford University Press.

Cuadra, C. B. (2011). Right of access to health care for undocumented migrants in EU: A comparative study of national policies. European Journal of Public Health, 22(2), 267-271.

Czaika, M. (2015). Migration and economic prospects. Journal of Ethnic and Migration Studies, 41 (1), 58-82.

Davies, A. A., Basten, A., \& Frattini, C. (2009). Migration: A social determinant of the health of migrants. Geneva: International Organization for Migration. 
De Giorgi, G., \& Pellizzari, M. (2009). Welfare migration in Europe. Labour Economics, 16(4), 353-363.

Devillanova, C., \& Frattini, T. (2016). Inequities in immigrants' access to health care services: Disentangling potential barriers. International Journal of Manpower, 37(7), 1-29.

Dustmann, C., \& Frattini, T. (2014). The fiscal effects of immigration to the UK. The Economic Journal, 124(580), 593-643.

Dustmann, C., Frattini, T., \& Halls, C. (2010). Assessing the fiscal costs and benefits of A8 migration to the UK. Fiscal Studies, 31, 1-41.

Dustmann, C., Fasani F., Frattini T., Minal L., \& Schonberg U. (2016). On the economics and politics of refugee migration (Centro Studi Luca D'Agliano Development Studies Working Papers N. 403). Turin.

Eikemo, T. A., Bambra, C., Judge, K., \& Ringdal, K. (2008a). Welfare state regimes and differences in self-perceived health in Europe: A multilevel analysis. Social Science \& Medicine, 66, 2281-2295.

Eikemo, T. A., Huisman, M., Bambra, C., \& Kunst, A. E. (2008b). Health inequalities according to educational level in different welfare regimes: A comparison of 23 European countries. Sociology of Health \& Illness, 30(4), 565-582.

Esping-Andersen, G. (1990). The three worlds of welfare capitalism. Princeton, NJ: Princeton University Press.

Essink-Bot, M. L., Lamkaddem, M., Jellema, P., Nielsen, S. S., \& Stronks, K. (2012). Interpreting ethnic inequalities in healthcare consumption: A conceptual framework for research. European Journal of Public Health, 23(6), 922-926.

Eurobarometer. (2014). Patient safety and quality of care: Report. Special Eurobarometer n. 41.

European Agency for Fundamental Rights (FRA). (2011). Migrants in an irregular situation: Access to healthcare services in 10 European Union Member States. Vienna: FRA.

European Commission. (2013). Health inequities in the EU: Final report of a consortium. Consortium lead: Sir Michael Marmot.

Eurostat. (2017). Migration and migrant population statistics explained, Brussels. Accessed November 28, 2018.

Ferrera, M. (1996). The "Southern model" of welfare in social Europe. Journal of European Social Policy, 6, 17-37.

Fouarge, D., \& Ester, P. (2007). Factors determining international and regional migration in Europe. European Foundation for the Improvement of Living and Working Conditions (EUROFOUND), Dublin.

Gee, E. R., \& Giuntella, G. O. (2011). Medicaid and ethnic networks. The BE Journal of Economic Analysis \& Policy, 11(1), 1-31.

Giannoni, M., Franzini, L., \& Masiero, G. (2016). Migrant integration policies and health inequalities in Europe. BMC Public Health, 16, 463, 1-14.

Gimeno-Feliu, L. A., Calderón-Larrañaga, A., Diaz, E., Poblador-Plou, B., Macipe-Costa, R., \& Prados-Torres, A. (2016). Global healthcare use by immigrants in Spain according to morbidity burden, area of origin, and length of stay. BMC Public Health, 16(450), 1-12.

Giuntella, O. (2013). Why does the health of immigrants deteriorate? Evidence from birth records (IZA Discussion Paper No. 7588). Bonn.

Giuntella, O. (2016). Assimilation and health: Evidence from linked birth records of second- and third-generation Hispanics. Demography, 53, 1976-2004.

Giuntella, O., \& Mazzonna, F. (2015). Do immigrants improve the health of natives? Journal of Health Economics, 43, 140-153.

Giuntella, O., \& Stella, L. (2017). The acceleration of immigrant unhealthy assimilation. Health Economics, 26, 511-518.

Giuntella, O., Nicodemo, C., \& Vargas Silva, C. (2016). The impact of immigration on health and health care: Evidence from the United Kingdom. In F. Fasani (Ed.), Refugees and economic migrants: Facts, policies and challenges (VoxEU.org Book) (pp. 99-114). London: CEPR Press. 
Grönqvist, H., Johansson, P., \& Niknami, S. (2012). Income inequality and health: Lessons from a Refugee Residential Assignment Program (IZA Discussion Paper No. 6554). Bonn.

Grosser, A., Razum, O., Vrijkotte, T. G. M., Hinz, I.-M., \& Spallek, J. (2016). Inclusion of migrants and ethnic minorities in European birth cohort studies: A scoping review. European Journal of Public Health, 26, 1-6.

Grossman, M. (1972). On the concept of health capital and the demand for health. Journal of Political Economy, 80(2), 223-249.

Gubert, F., \& Senne, J.N. (2016). Is the European Union attractive for potential migrants? An investigation of migration intentions across the world (OECD Social, Employment and Migration Working Papers, No. 188). Paris: OECD.

Hadjar, A., \& Backes, S. (2013). Migration background and subjective well-being: A multilevel analysis based on the European Social Survey. Comparative Sociology, 12, 645-676.

Hansen, J., \& Lofstrom, M. (2003). Immigrant assimilation and welfare participation: Do immigrants assimilate into or out of welfare? Journal of Human Resources, 38(1), 74-98.

Harris, J. R., \& Todaro, M. P. (1970). Migration, unemployment and development: A two-sector analysis. The American Economic Review, 60, 126-142.

Hatton, T.J., \& Williamson, J.G. (2002). What fundamentals drive world migration? (NBER Working Paper No. 9159). National Bureau of Economic Research.

Honorati, M., Gentilini, U., \& Yemtsov, R. (2015). The state of social safety nets 2015. Washington, DC: World Bank Group.

Ikram, U. Z., Snijder, M. B., Fassaert, T. J. L., Schene, A. H., Kunst, A. E., \& Stronks, K. (2015). The contribution of perceived ethnic discrimination to the prevalence of depression. European Journal of Public Health, 25, 243-248.

Ingleby, D. (2012). Ethnicity, migration and the social determinants of health agenda. Psychosocial Intervention, 21, 331-341.

Ingleby, D., Krasnik, A., Lorant, V., \& Razum, O. (Eds.). (2012). Health inequalities and risk factors among migrants and ethnic minorities. Maku, Belgium.

International Labour Organization. (2014). World social protection report 2014-15. Geneva: International Labor Organization.

International Organization for Migration. (2017). Accessed November 28, 2018, from http:// migration.iom.int/europe/

Jayaweera, H., \& Quigley, M. (2010). Health status, health behaviour and healthcare use among migrants in the UK: Evidence from mothers in the Millennium Cohort Study. Social Science \& Medicine, 71, 1002-1010.

Kahneman, D., \& Tversky, A. (1979). Prospect theory: An analysis of decision under risk. Econometrica, 47(2), 263-291.

Katz, E., \& Stark, O. (1986). Labor migration and risk aversion in less developed countries. Journal of Labor Economics, 4(1), 134-149.

Levecque, K., \& Van Rossem, R. (2015). Depression in Europe: Does migrant integration have mental health payoffs? A cross-national comparison of 20 European countries. Ethnic Health, 20, 49-65.

Lindert, J., von Ehrenstein, O. S., Priebe, S., Mielck, A., \& Brahler, E. (2009). Depression and anxiety in labor migrants and refugees - A systematic review and meta-analysis. Social Science \& Medicine, 69, 246-257.

Mackenbach, J. P. (2012). The persistence of health inequalities in modern welfare states: The explanation of a paradox. Social Science \& Medicine, 75(4), 761-769.

Malmusi, D. (2014). Immigrants' health and health inequality by type of integration policies in European countries. European Journal of Public Health, 25(2), 293-299.

Malmusi, D., Borrell, C., \& Benach, J. (2010). Migration-related health inequalities: Showing the complex interactions between gender, social class and place of origin. Social Science \& Medicine, 71(9), 1610-1619.

Mankiw, G. N. (1998). Principles of microeconomics. Stanford: Cenage Learning/South-Western College. 
Marmot, M. G. (2005). Social determinants of health inequalities. Lancet, 365, 1099-1104.

Marmot, M. G., Allen, J., Bell, R., Bloomer, E., \& Goldblatt, P. (2012). WHO European review of social determinants of health and the health divide. Lancet, 380(15), 1011-1029.

Massey, D. S., Arango, J., Hugo, G., Kouaouci, A., Pellegrino, A., \& Taylor, J. E. (1993). Theories of international migration: A review and appraisal. Population and Development Review, 19(3), 431-466.

Meuleman, B., \& Reeskens, T. (2008). The relation between integration policy and majority attitudes toward immigration: An empirical test across European countries. Paper presented at the Dag van de Sociologie, Leuven.

Mladovsky, P. (2011). Migrant health policies in Europe. In B. Rechel, P. Mladovsky, W. Devillé, B. Rijks, R. Petrova-Benedict, \& M. McKee (Eds.), Migration and health in the European Union (pp. 185-202). Maidenhead: Open University Press.

Moullan, Y., \& Jusot, F. (2014). Why is the "healthy migrant effect" different between European countries? European Journal of Public Health, 24(1), 80-86.

Münz, R. (2017). The integration of migrants and refugees: A European synopsis. In R. Bauböck \& M. Tripkovic (Eds.), The integration of migrants and refugees (pp. 7-19). Florence: European University Institute, Robert Schuman Centre for Advanced Studies.

Musgrave, R. A. (1959). The theory of public finance: A study in public economy. New York: McGraw-Hill.

Navarro, V., et al. (2003). The importance of the political and the social in explaining mortality differentials among the countries of the OECD, 1950-1998. International Journal of Health Services Research, 33, 419-494.

Navarro, V., et al. (2006). Politics and health outcomes. Lancet, 368(9540), 1033-1037.

Organization for Economic and Cooperation Development. (2017). Interrelations between public policies, migration and development. Paris: OECD Publishing.

Orrenius, P. M., \& Zavodny, M. (2013). Chapter 11: Immigrants in risky occupations. In A. Constant \& K. F. Zimmermann (Eds.), International Handbook on the Economics of Migration. Cheltenham: Edward Elgar.

Pedersen, P. J., Pytlikova, M., \& Smith, N. (2008). Selection and network effects: Migration flows into OECD countries 1990-2000. European Economic Review, 52(7), 1160-1186.

Petretto, A. (2017). Economics of Institutions and Law. Florence: DISEI.

Preston, I. (2014). The effect of migration on public finances. The Economic Journal, 124, $569-592$.

Razum, O. (2006). Commentary: Of salmon and time travelers: Musing on the mystery of migration mortality. International Journal of Epidemiology, 34, 919-921.

Razum, O., \& Twardella, D. (2002). Time travel with Oliver Twist: Towards an explanation for a paradoxically low mortality among recent immigrants. Tropical Medicine and International Health, 7(1), 4-10.

Razum, O., Zeeb, H., \& Rohrmann, S. (2001). The healthy migrant effect: Not merely a fallacy of inaccurate denominator figures. International Journal of Epidemiology, 29, 191-192.

Rechel, B., Mladovsky, P., Devillé, W., Rijks, B., Petrova-Benedict, R., \& McKee, M. (Eds.). (2011). Migration and health in the European Union. Maidenhead: Open University Press.

Rechel, B., Mladovsky, P., Ingleby, D., Mackenbach, J. P., \& McKee, M. (2013, April). Migration and health in an increasingly diverse Europe. Lancet, 381, 1235-1245.

Samuelson, P. (1954). The pure theory of public expenditure. The Review of Economics and Statistics, 3(4), 387-389.

Sander, M. (2007). Return migration and the "healthy immigrant effect" (SOEP papers on Multidisciplinary Panel Data Research N. 60).

Sarvimäki, M. (2011). Assimilation to a welfare state: Labor market performance and use of social benefits by immigrants to Finland. Scandinavian Journal of Economics, 113(3), 665-688.

Simon, H. A. (1983). Reason in human affairs. Stanford: Stanford University Press.

Sjaastad, L. A. (1962). The costs and returns of human migration. Journal of Political Economy, 70 (5), 80-93. 
Smith Nielsen, S., \& Krasnik, A. (2010). Poorer self-perceived health among migrant and ethnic minorities versus the majority population in Europe. International Journal of Public Health, 55, 357-371.

Stanciole, A. E., \& Huber, M. (2009). Access to healthcare for migrants, ethnic minorities and asylum seekers in Europe. In Policy Brief. Vienna: European Centre for Social Welfare and Policy Research.

Stark, O. (1978). Economic-demographic interactions in agricultural development: The case of rural-to-urban migration. Rome: Food and Agriculture Organization.

Stark, O. (1991). The migration of labor. Malden, MA: Basil Blackwell.

Steventon, A., \& Bardsley, M. (2011). Use of secondary care in England by international immigrants. Journal of Health Services Research \& Policy, 16(2), 90-94.

Suess, A., Ruiz Perez, I., Ruiz Azarola, A., \& March Cerdà, J. C. (2014). The right of access to health care for undocumented migrants: A revision of comparative analysis in the European context. European Journal of Public Health, 24(5), 712-720.

Thomson, S., Foubister, T., \& Mossialos, E. (2009). Financing health care in the European Union. Copenhagen: WHO Regional Office for Europe.

Todaro, M. P. (1969). A model of labor migration and urban unemployment in less developed countries. The American Economic Review, 59, 138-148.

United Nations Department of Economic and Social Affairs. (2017). Trends in international migrant stock: The 2017 revision. New York.

United Nations High Commissioner for Refugees. (2017). Accessed November 28, 2018 from http://data.unhcr.org/mediterranean/regional.php

Wadsworth, J. (2013). Mustn't grumble: Immigration, health and health service use in the UK and Germany. Fiscal Studies, 34(1), 55-82.

Wadsworth, J., Dhingra, S., Ottaviano, G., \& Van Reenen, J. (2016). Brexit and the impact of immigration on the UK (Centre for Economic Performance Paper Brexit 05). London School of Economics.

World Health Organization. (2010). How health systems can address health inequities linked to migration and ethnicity. Copenhagen: Regional Office for Europe.

World Health Organization and World Bank. (2015). Tracking universal health coverage: First global monitoring report. Geneva/Washington, DC: World Health Organisation and World Bank Group.

Open Access This chapter is licensed under the terms of the Creative Commons Attribution 4.0 International License (http://creativecommons.org/licenses/by/4.0/), which permits use, sharing, adaptation, distribution and reproduction in any medium or format, as long as you give appropriate credit to the original author(s) and the source, provide a link to the Creative Commons licence and indicate if changes were made.

The images or other third party material in this chapter are included in the chapter's Creative Commons licence, unless indicated otherwise in a credit line to the material. If material is not included in the chapter's Creative Commons licence and your intended use is not permitted by statutory regulation or exceeds the permitted use, you will need to obtain permission directly from the copyright holder.

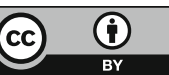

